\title{
A new early occurrence of Cervidae in North America from the Miocene-Pliocene Ellensburg Formation in Washington, USA
}

\author{
Meaghan M. Emery-Wetherell and Joseph F. Schilter
}

\begin{abstract}
A new fossil cervid from the Craig's Hill locality of the Miocene-Pliocene Ellensburg Formation in the State of Washington, USA, may be one of the oldest fossil deer yet found in North America, underlying a date of $4.9 \mathrm{Ma} \pm 0.1 \mathrm{Ma}$. This mandible fragment with $\mathrm{m} 2, \mathrm{~m} 3$, and associated $\mathrm{p} 2$ has a size that does not distinguish it from Bretzia pseudalces, Odocoileus hemionus, or Capreolus constantini, and distinguishes it from Eocoileus gentryorum and Odocoileus lucasi only in having a thinner p2. A strong paraconid on the p2, and ectostylids and cingulids on the $\mathrm{m} 2$ and $\mathrm{m} 3$ link it most strongly with Bretzia pseudalces, but these are also intermittently present in Odocoileus hemionus. Because of the close geographic and temporal proximity of Bretzia pseudalces in the Ringold Formation, and its shared morphology with Bretzia, we are tentatively assigning this specimen to cf. Bretzia.
\end{abstract}

Meaghan M. Emery-Wetherell. Central Washington University, 400 E University Way, Ellensburg, Washington, USA. Meaghan.wetherell@cwu.edu

Joseph F. Schilter. Shannon \& Wilson, 400 N 34th St \#100, Seattle, Washington, USA.

Joseph.schilter@gmail.com

Keywords: Cervidae; Bretzia; Pliocene; Odocoileus

Submission: 20 November 2018. Acceptance: 18 February 2020.

\section{INTRODUCTION}

The available evidence suggests that Cervidae arrived in North America around 5 million years (Ma) ago and dispersed into South America by approximately $1.5 \mathrm{Ma}$ (Webb, 2000; JiménezHidalgo and Bravo-Cuevas, 2014). The early occurrences of Cervidae in North America are sparse (Jiménez-Hidalgo and Bravo-Cuevas,
2014; Gustafson, 2015), with two localities contending for the earliest record: Bretzia pseudalces from the Ringold Formation in Washington at 4.98 Ma-4.89 Ma (Gustafson, 2015), and Eocoileus gentryorum from the Palmetto local fauna of Florida, USA, at $5 \mathrm{Ma}-4.7 \mathrm{Ma}$ (Webb et al., 2008). Odocoileus sp. has also been identified in the Palmetto local fauna of Florida, though it has not been for-

Emery-Wetherell, Meaghan M. and Schilter, Joseph F. 2020. A new early occurrence of Cervidae in North America from the MiocenePliocene Ellensburg Formation in Washington, USA. Palaeontologia Electronica, 23(1):a08. https://doi.org/10.26879/946 palaeo-electronica.org/content/2020/2939-new-old-deer-from-washington 


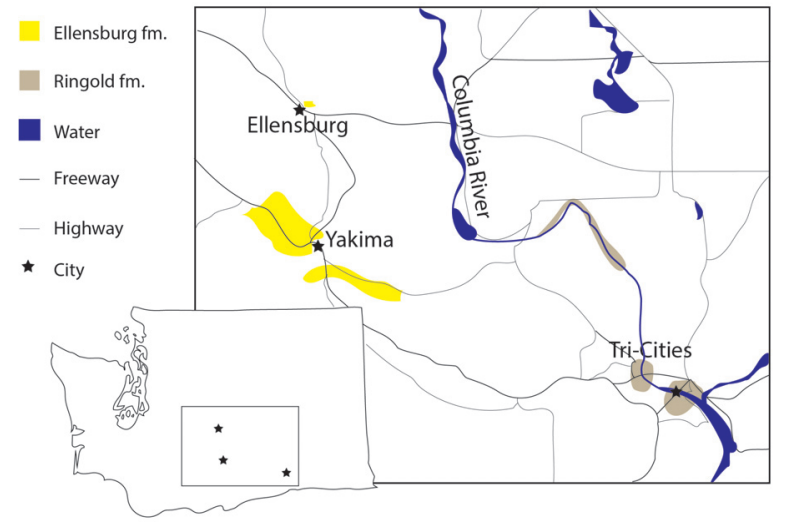

FIGURE 1. Map of relevant Miocene and Pliocene sedimentary outcrops in Central Washington. Inset map shows approximate location in the state. Adapted from Gustafson (2015) and Smith (1988b).

mally described (Gustafson, 2015). Voorhies and Perkins (1998) did mention in an abstract the occurrence of an antler assigned to cf. Bretzia, coming from below the Santee Ash bed, which has been dated at $5.0 \mathrm{Ma} \pm 0.2 \mathrm{Ma}$ using fission tracks (Boellstorf, 1976), but the specimen has not been formally published.

We here describe a new cervid occurrence from the Miocene-Pliocene Ellensburg Formation in Central Washington. This new cervid occurrence is below a date of 5.0 Ma-4.8 Ma, making it one of the oldest cervid occurrences in North America.

\section{GEOLOGICAL SETTING}

The Ellensburg Formation is a Miocene-Pliocene sedimentary rock unit from central Washington, USA (Figure 1). It is comprised of a suite of sedimentary deposits interleaved with and overlying the Columbia River flood basalts (Figure 2) (Smith, 1988a). These sediments include epiclastic and volcaniclastic rocks, which are predominately sourced from the Cascades (Reidel and Campbell, 1989). The Ellensburg formation is divided up into several members and loosely described in terms of the Lower Ellensburg formation, overlying the Grand Ronde Basalt dated at $17 \mathrm{Ma}$ (Smith et al., 1988), and the Upper Ellensburg, beginning above the 11.5-million-year-old Pomona Member of the Saddle Mountains Basalt (Smith, 1988b). Upper Ellensburg sediments include conglomerates, lahars, fluvial sandstone, mudstone, and lacustrine laminations (Smith, 1988a). Previous research has revealed fossil localities in the Upper Ellensburg
Formation (Martin and Mallory, 2011), with an associated date of $7.41 \mathrm{Ma} \pm 0.36 \mathrm{Ma}$. The uppermost age of the Ellensburg formation is $4.7 \mathrm{Ma}$, with the youngest known material appearing in the Yakima basin (Smith, 1988b).

Craig's Hill is a locality in the middle of the fairgrounds and adjacent city property in Ellensburg, Washington, which spans the Upper Ellensburg Formation into Pleistocene and Holocene soils (Lamb, 1997). The sedimentology of the Craig's Hill locality has been described (Waitt, 1979; Lamb, 1997), but to our knowledge no fossils have been described from this locality. The specimen described here and other fragments of bone and enamel were found weathering out from a paleosol underlying gravels from the Upper Ellensburg Formation (Figure 3).

An unpublished undergraduate thesis dated a sample of a tephra layer at the base of the gravels directly overlaying the paleosol (Lamb, 1997). This date was $4.9 \mathrm{Ma} \pm 0.1 \mathrm{Ma}$, considerably younger than previous estimates of $10 \mathrm{Ma}-8 \mathrm{Ma}$ for the Kittitas basin sections of the Ellensburg Formation (Smith, 1988b; Lamb, 1997). Because cervids are not known from North America prior to 5 million years ago (Webb, 2000; Jiménez-Hidalgo and Bravo-Cuevas, 2014), the discovery of a cervid fossil in the Ellensburg Formation at the base of this outcrop, described here, is consistent with this younger date.

The nearby Ringold Formation (Figure 1) is of similar age and sedimentological setting, with abundant Pliocene vertebrates. Though currently regarded as separate, the Ringold Formation is occasionally treated as a member of the Ellensburg Formation (e.g., Smith, 1988b).

\section{MATERIALS AND METHODS}

The specimen University of Washington Burke Museum (UWBM) VP 117138 (Figure 4) was spotted weathering out of the hill in the fall of 2016 by a graduate student at Central Washington University, and left in place over the course of the winter while permission was obtained from the county to remove the fossil. When initially discovered, the mandible and premolar were connected; after a winter's worth of weathering, they were not, and the connecting bone was not recovered. The specimen is stored at the Burke Museum of Natural History in Seattle, Washington. 


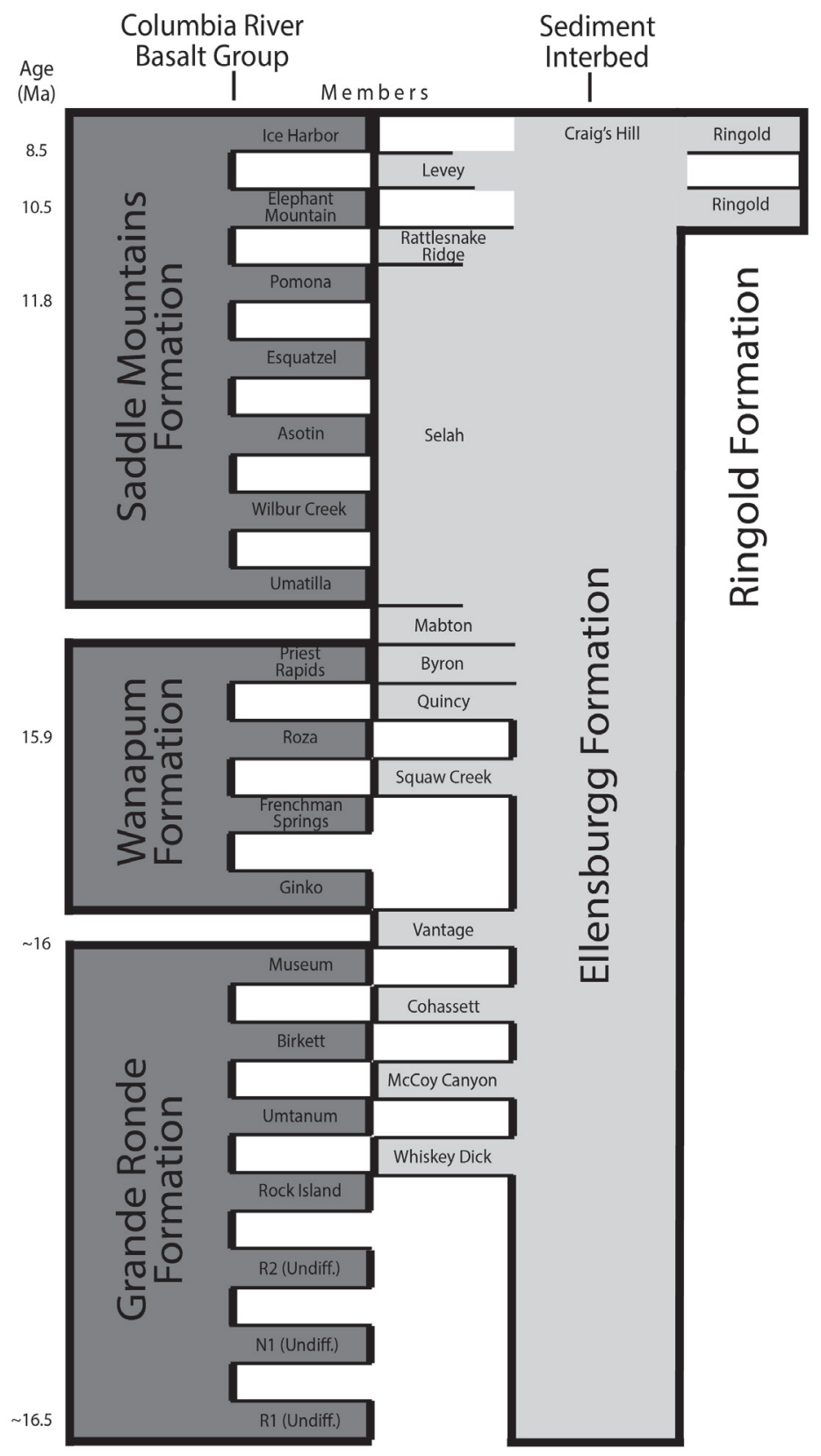

FIGURE 2. Generalized stratigraphic column of the Columbia River Basalts and sedimentary interbeds. The Ringold Formation is shown here as separate, but the formation overlaps temporally with the Ellensburg Formation and may not be distinct. Named members of the Ellensburg Formation are shown in stratigraphic sequence. Short lines in between interbeds indicate only generalized stratigraphy, while longer lines indicate a hard time/unit boundary for all members. The Craig's Hill locality is identified in sequence. Adapted from Smith et al. (1988) and Kasbohm and Schoen (2018).

\section{SYSTEMATIC PALEONTOLOGY}

Class MAMMALIA Linnaeus, 1758

Order ARTIODACTYLA Owen, 1848

Family CERVIDAE Gray, 1821

Bretzia Fry and Gustafson, 1975 cf. Bretzia sp.
Referred specimens. UWBM VP 117138, a partial right mandible with $\mathrm{m} 2$ and $\mathrm{m} 3$, and associated $\mathrm{p} 2$. Comparative material. We compared this specimen to jaws of extant Odocoileus hemionus from the state of Oregon that are curated at the University of Oregon Museum of Natural History: B21654, B-21655, B-21660, B-21672, B-21677, B- 


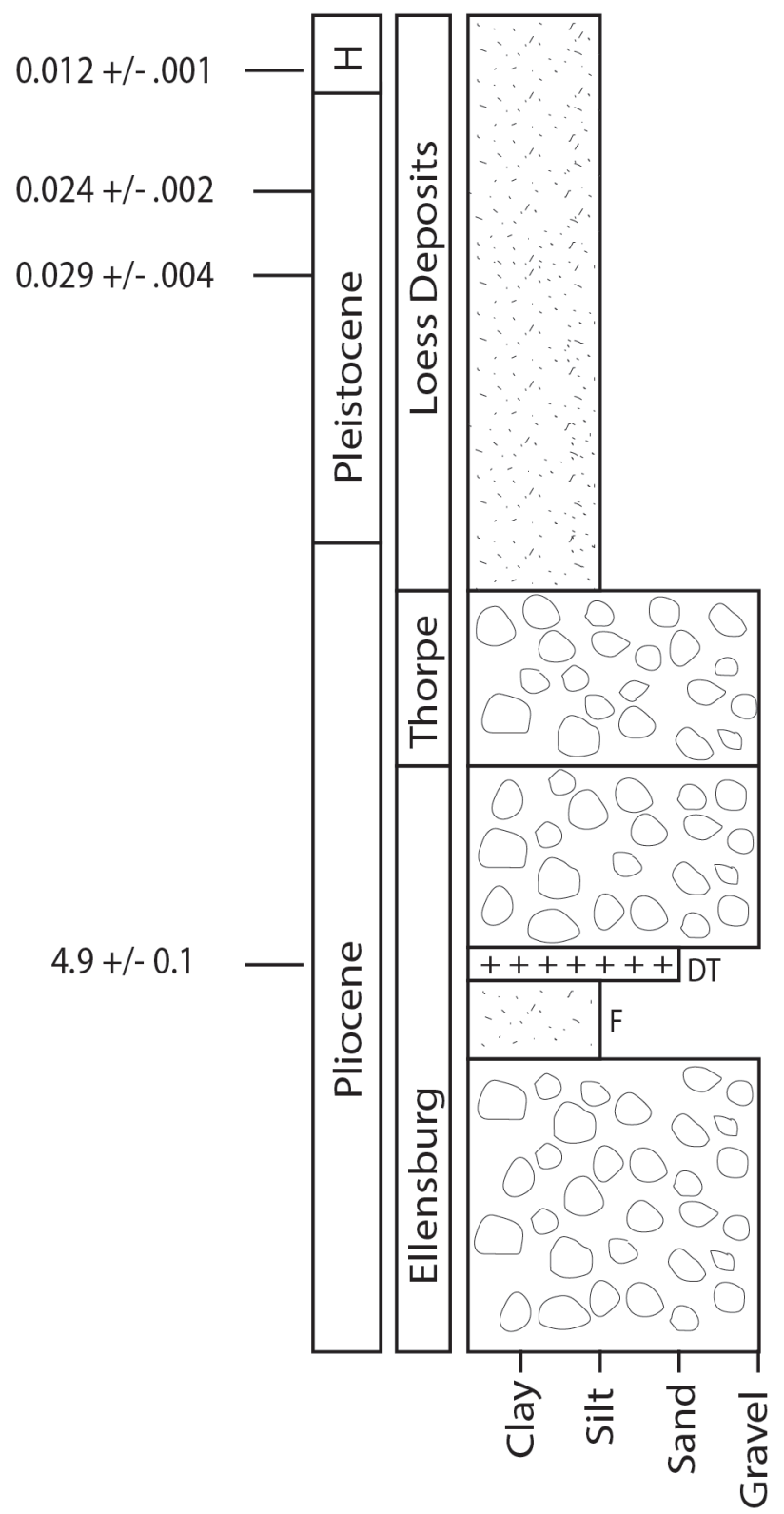

FIGURE 3. Generalized stratigraphic sequence of Craig's Hill locality, showing approximate positions of dates from Lamb (1997). Abbreviations: DT, dated tephra; F, overbank deposit with fossil.

21681, B-21687, B-21688, B-21690, and B-21693. Measurements and character coding are available in Appendix 1.

Occurrence. Locality C2907, a vertical outcrop of the Ellensburg Formation and Thorp Formation, capped by Pleistocene loess and soils. Other nondiagnostic material was found at the locality, including bone scraps and a disassociated fragment of enamel. All vertebrate material was found in the paleosol underlying the Ellensburg gravel deposits.
Description. The strong ectostylid on $\mathrm{m} 2$ and $\mathrm{m} 3$, clear molar metastylids, and unfused molar postmetacristid and pre-entocristid place this mandible firmly in the family Cervidae. Of the three species previously known from the Pliocene and Pleistocene of Central Washington, UWBVM VP 117138 is close in size to both Bretzia pseudalces and Odocoileus ensifer (Fry and Gustafson, 1975). Odocoileus ensifer is very similar in size and morphology to Odocoileus hemionus (Fry and Gustafson, 1975), and may be a junior synonym (Anderson and Wallmo, 1984). Given this and the 

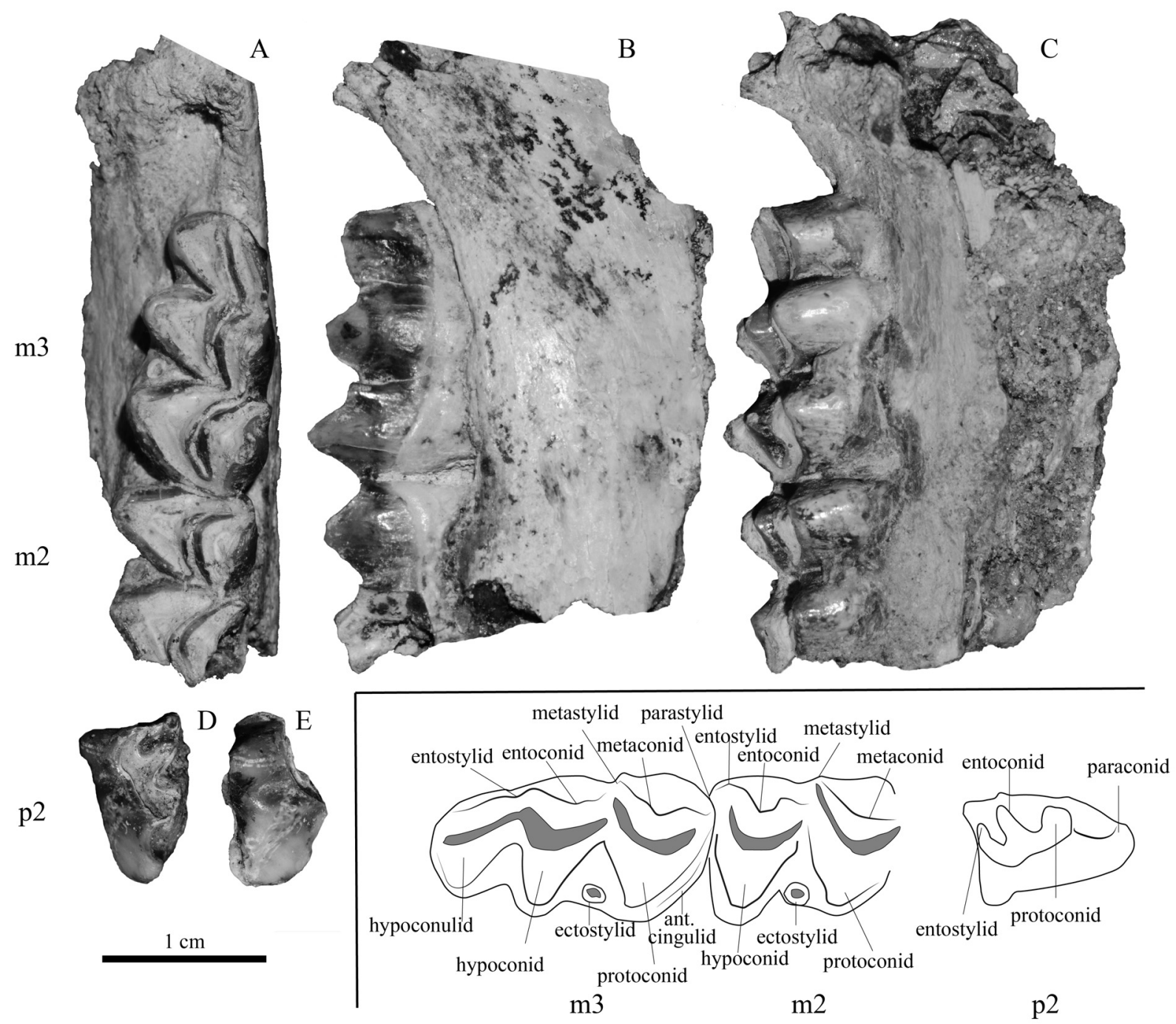

FIGURE 4. Specimen UWBM VP 117138, cf. Bretzia, right mandible fragment with $\mathrm{m} 2$ and $\mathrm{m} 3$ in occlusal (A), lingual (B), and labial (C) views, and associated p2 in occlusal (D) and labial (E) views. Dental nomenclature (F) follows Gustafson (2015). Scale bar equals $1 \mathrm{~cm}$.

lack of dental material for Odocoileus ensifer, we compared our material to Odocoileus hemionus as per Gustafson (2015), as well as Odocoileus lucasi as figured in Morejohn and Dailey (2004). Bretzia nebrascensis (Gunnell and Foral, 1994) is also a possibility, but only antlers have been described, and thus a comparison with our material was not possible. Eocoileus gentryorum (Webb, 2000) and Capreolus constantini (Vislobokova et al., 1995; Jiménez-Hidalgo and Bravo-Cuevas, 2014) are also considered here.

The measurements taken on both molars of UWBM VP 117138 are within two standard deviations of all measurements of Odocoileus, Eocoileus, and Capreolus molars (Table 1). Two standard deviation contain $95 \%$ of possible measurements in a normal distribution (Zar, 1999), and thus is useful as a cutoff for expected variations from the average size. Molar widths of UWBM VP 117138 are within two standard deviations of the measurements taken on the molars of Bretzia, but are smaller than two standard deviations of the lengths reported by Gustafson (2015). Artiodactyl teeth do decrease in length as they are worn (EmeryWetherell and Davis, 2018), and the significantly worn molars of UWBM VP 117138 may be the cause of their smaller size. It is also worth noting that the Coefficients of Variation (CV) provided by Gustafson (2015) for $\mathrm{m} 2$ and $\mathrm{m} 3$ lengths of Bretzia (m2: $\mathrm{CV}=6.06 \% ; \mathrm{m} 3: \mathrm{CV}=4.67 \%$ ) are smaller than those we measured for Odocoileus (m2: CV = $7.81 \%$; m3: CV $=18.27 \%$ ), and are much smaller 
TABLE 1. Summary statistics of Bretzia pseudalces (Gustafson, 2015), 10 specimens of Odocoileus hemionus, one specimen of Odocoileus lucasi (Morejohn and Dailey 2004), Eocoileus gentryorum (Webb, 2000), Capreolus constantini (Vislobokova et al., 1995; Jiménez-Hidalgo and Bravo-Cuevas, 2014), and UWBM VP 117138. Summary statistics are averages in millimeters, plus or minus one standard deviation except in the case of UWBM VP 117138, which is the actual measurement of a single specimen. Asterisks indicate cases where UWBM VP 117138 is within two standard deviations of a species average. Abbreviations: AP, anteroposterior measurement; LL, labiolingual measurement.

\begin{tabular}{|c|c|c|c|c|c|c|}
\hline & \multicolumn{2}{|c|}{ p2 } & \multicolumn{2}{|c|}{ m2 } & \multicolumn{2}{|c|}{ m3 } \\
\hline & AP & LL & AP & LL & AP & LL \\
\hline Bretzia pseudalces & $11.02^{*}+/-0.39$ & $6.03^{*}+/-0.36$ & $15.79+/-0.60$ & $11.01^{*}+/-0.67$ & $21.63+/-1.01$ & $10.94^{*}+/-0.72$ \\
\hline Odocoileus hemionus & $8.97^{*}+/-0.77$ & $5.43^{*}+/-0.67$ & $16.01^{*}+/-1.25$ & $10.10^{*}+/-0.80$ & $20.00^{*}+/-3.64$ & $9.75^{*}+/-0.58$ \\
\hline Odocoileus lucasi & 18.0 & 9.0 & - & - & - & - \\
\hline Eocoileus gentryorum & $9.8^{*}+/-1.0$ & $5.3+/-0.5$ & $13.8^{*}+/-1.8$ & $9.2^{*}+/-1.0$ & $18.4^{*}+/-1.0$ & $9.1^{*}+/-1.8$ \\
\hline Capreolus constantini & $9.25^{\star}+/-0.5$ & $6.0^{*}+/-0.6$ & $13.73^{*}+/-.78$ & $10.06^{*}+/-0.51$ & $19.41^{*}+/-0.93$ & $10.24^{*}+/-0.47$ \\
\hline UWBM VP 117138 & 9.85 & 6.45 & 13.82 & 10.59 & 19.22 & 10.16 \\
\hline
\end{tabular}

than is typical for artiodactyl teeth (EmeryWetherell and Davis, 2018). Given that, it is possible that the averages and standard deviation reported by Gustafson (2015) are conservative, and that measurements taken on UWBM VP 117138 are within two standard deviations of all dental measurements of both species.

Morphologically, the molars of UWBM VP 117138 are most similar to those of Bretzia (Table 2). Both $\mathrm{m} 2$ and $\mathrm{m} 3$ of UWBM VP 117138 have a prominent ectostylid. Ectostylids are present in both Bretzia and Odocoileus, but are often absent in Odocoileus (Gustafson, 2015). Of the 10 Odocoileus jaws evaluated by the authors, none had an ectostylid as robust as that of UWBM VP 117138, five were lacking the $\mathrm{m} 3$ ectostylid, and six were lacking an $\mathrm{m} 2$ ectostylid.

Like Bretzia and Capreolus, UWBM VP 117138 has a cingulid on m3. Like Odocoileus hemionus, Odocoileus lucasi, and Eocoileus gentryorum, UWBM VP 117138 does not have a cingulid on m2 (Table 2). Molar cingulids are highly variable in single-location samples of fossil artiodactyl dentition and their absence or presence may not be diagnostic (Emery et al., 2016). It is, therefore, possible that while UWBM VP 117138 did not have an $\mathrm{m} 2$ cingulid, other members of the population did, and this absence may not be diagnostic.

The p2 of UWBM VP 117138 is within two standard deviations of the lengths and widths of Bretzia, Capreolus, and Odocoileus hemionus, but exceeds two standard deviations of the average width of Eocoileus and is nearly half the length of Odocoileus lucasi (Table 1). The CV of p2 widths of Eocoileus reported by Vislobokova (1995) was 9.6 $\%$, which is similar to the measured variation in Odocoileus in this study and is closer to what is expected for a mid-sized artiodactyl (Emery-
Wetherell and Davis, 2018), and therefore the difference in size between our specimen and Eocoileus is likely biologically meaningful. Odocoileus lucasi is considerably larger, with a p2 length approximately twice as long as any of the other species we considered - on par with the size of Cervus elaphus. This is far outside the expected size range for our specimen, and disqualified $O$. lucasi as a possible identification.

Morphologically, the p2 has a strong paraconid, similar to Eocoileus and Bretzia, and dissimilar to Capreolus (Vislobokova, 1995; Webb, 2000; Gustafson, 2015). Gustfason (2015) reports the paraconid as being present in Bretzia, and either absent or weakly present in Odocoileus hemionus. In our sample of Odocoileus hemionus, five of nine specimens with a p2 had no obvious paraconid, two had a weakly present paraconid, and two had a prominent paraconid, confirming the findings of Gustafson (2015). The figured p2 of Odocoileus lucasi in Morejohn and Dailey (2004) is worn, but appears to have a prominent paraconid as well.

Overall, the specimen morphologically overlaps with many cervid species of the same age (Table 2) and is similar in size to most as well (Table 1). The closest morphological match is Bretzia or Odocoileus hemionus. As there is considerable morphological similarity to Bretzia, which is found in the nearby and similarly-aged Ringold Formation, we have tentatively assigned UWBM VP 117138 to cf. Bretzia.

\section{DISCUSSION AND CONCLUSIONS}

In size, UWBM VP 117138 is only distinguishable from Odocoileus lucasi and Eocoileus gentryorum. Odocoileus lucasi is much larger, and while Eocoileus is similar in most measurements, it has a 
TABLE 2. Summary of diagnostic morphological criteria of Bretzia and Odocoileus as specified in Gustafson (2015), Odocoileus lucasi as figured in Morejohn and Dailey (2004, figure 3), Eocoileus gentryorum (Webb, 2000), Capreolus constantini (Vislobokova et al .1995; Jiménez-Hidalgo and Bravo-Cuevas, 2014), and morphology of UWBM VP 117138. 0 indicates absence, 1 indicates presence, and 0/1 indicates variable presence or absence. No description of molars was provided in Webb (2000), morphology of m2 and m3 was coded after Webb (2000, figure 4.8).

\begin{tabular}{|c|c|c|c|c|c|c|}
\hline & \multicolumn{2}{|r|}{ p2 } & \multicolumn{2}{|c|}{$\mathrm{m} 2$} & \multicolumn{2}{|c|}{ m3 } \\
\hline & Cingulid & Strong Paraconid & Ectostylid & Cingulid & Ectostylid & Cingulid \\
\hline Bretzia pseudalces & 0 & 1 & 1 & 1 & 1 & 1 \\
\hline Odocoileus hemionus & 0 & $0 / 1$ & $0 / 1$ & 0 & $0 / 1$ & 0 \\
\hline Odocoileus Iucasi & 0 & 1 & 0 & 0 & $?$ & $?$ \\
\hline Eocoileus gentryorum & 1 & 1 & 0 & 0 & 0 & 0 \\
\hline Capreolus constantini & $?$ & 0 & 1 & 1 & 1 & 1 \\
\hline UWBM VP 117138 & 0 & 1 & 1 & 0 & 1 & 1 \\
\hline
\end{tabular}

p2 that is thinner than our specimen. In all other measurements UWBM VP 117138 is indistinguishable from nearly all considered species, except Odocoileus lucasi. Though the lengths of $\mathrm{m} 2$ and $\mathrm{m} 3$ are smaller than two standard deviations of Bretzia, the population of Bretzia measured by Gustafson (2015) is far less variable than is typical in mid-sized artiodactyls (Emery-Wetherell and Davis, 2018). The maximum lengths of artiodactyl teeth are often smaller in older adults with worn teeth (Emery-Wetherell and Davis, 2018), and given that UWBM VP 117138 is very worn, it is possible it is simply older and therefore smaller than the measured specimens of Bretzia reported by Gustafson (2015), or that the size difference may arise only from being found at different localities.

Though UWBM VP 117138 has commonalities with Bretzia pseudalces, Odocoileus hemionus, Eocoileus gentryorum, and Capreolus constantini, it shares the most morphological features with Bretzia, as well as close geographic and temporal proximity. It is possible that UWBM VP 117138 does represent an unusual specimen of another Pliocene cervid, and so we tentatively refer this specimen to Bretzia with the acknowledgement that more material will clarify this identification.
The youngest previously published estimates for the Upper Ellensburg age are a date of $7.41 \mathrm{Ma}$ $\pm 0.36 \mathrm{Ma}$ (Martin and Mallory, 2011) and a mentioned unpublished date of $4.7 \mathrm{Ma}$ without provenance (Smith, 1988b). If the former published date was applicable, then this occurrence of Bretzia would be significantly older than the expected arrival time of Cervidae in North America. The date of 4.9 Ma $\pm 0.1 \mathrm{Ma}$ (Lamb, 1997) overlies our fossil and is more in line with other early occurrences of cervids. Thus, it is likely that this cervid mandible represents a younger uppermost age distribution for the Upper Ellensburg Formation in the Kittitas basin, rather than a significantly older incursion of cervids into North America. However, given that the paleosol containing the fossil is stratigraphically below the date, it is possible that considerable time passed between the deposition of the fossil and the deposition of the tephra - meaning that the mandible could be considerably older than $5.0 \mathrm{Ma}$.

\section{ACKNOWLEDGEMENTS}

L. Wetherell (Central Washington University) who found the specimen. L. Young (Kittitas County Fairgrounds) who worked with the City Council of Ellensburg to get the specimen transferred to the Burke Museum. J. Lamb who initially dated the material above the fossil.

\section{REFERENCES}

Anderson, A.E. and Wallmo, O.C. 1984. Odocoileus hemionus. Mammalian Species, 219:1-9. https://doi.org/10.2307/3504024

Boellstorff, J. 1976. The succession of late Cenozoic volcanic ashes in the Great Plains: a progress report. Kansas Geological Survey Guidebook Series, 1:37-71. 
Emery-Wetherell, M. and Davis, E.B. 2018. Dental measurements do not diagnose modern artiodactyl species: Implications for the systematics of Merycoidodontoidea. Palaeontologia Electronica, 21.2.23A:1-28. https://doi.org/10.26879/748

https://palaeo-electronica.org/content/2018/2202-dental-variation-of-artiodactyl

Emery, M.M., Davis, E.B., and Hopkins, S.S. 2016. Systematic reassessment of an agriochoerid oreodont from the Hancock Mammal Quarry, Clarno (Eocene, Duchesnean), Oregon. Journal of Vertebrate Paleontology, 36:e1041970. https://doi.org/10.1080/ 02724634.2015.1041970

Fry, W.E. and Gustafson, E.P. 1975. Cervids from the Pliocene and Pleistocene of central Washington. Journal of Paleontology, 48:375-386.

Gray, J.E. 1821. On the natural arrangement of vertebrose animals. The London Medical Repository, 15:296-310.

Gunnell, G.F. and Foral, A. 1994. New species of Bretzia (Cervidae; Artiodactyla) from the latest Pleistocene or earliest Holocene of Nebraska and South Dakota. Journal of Mammalogy, 75:378-381. https://doi.org/10.2307/1382556

Gustafson, E.P. 2015. An early Pliocene North American deer: Bretzia pseudalces, its osteology, biology, and place in cervid history. Bulletin of the Museum of Natural History, University of Oregon, 25:1-75.

Jiménez-Hidalgo, E. and Bravo-Cuevas, V.M. 2014. A roe deer from the Pliocene of Hidalgo, central Mexico. Acta Palaeontologica Polonica, 60:807-813. https://doi.org/10.4202/ app.00044.2013

Kasbohm, J. and Schoen, B. 2018. Rapid eruption of the Columbia River Flood Basalt and correlation with the mid-Miocene climate optimum. Science Advances, 4:eaat8223. https:// doi.org/10.1126/sciadv.aat8223

Lamb, J. 1997. Quaternary Stratigraphy of the Kittitas Valley, with Emphasis on the Craig's Hill Section. Senior Undergraduate Thesis, Central Washington University, Ellensburg, Washington.

Linnaeus, C. 1758. Systema Naturae per Regna Tria Naturae: Secundum Classes, Ordines, Genera, Species, cum Characteribus, Differentiis, Synonymis, Locis. Tomus I. 10th edition. Laurentii Salvii, Stockholm. https://doi.org/10.5962/bhl.title.542

Martin, J.E. and Mallory, V.S. 2011. Vertebrate paleontology of the Late Miocene (Hemphillian) Wilbur Locality of Central Washington. Paludicola, 8:155-185.

Morejohn, G.V. and Dailey, D.C. 2004. The identity and postcranial osteology of Odocoileus lucasi (Hay) 1927: a Plio-Pleistocene deer from California and Idaho. Sierra College Natural History Museum Bulletin, 1:1-54.

Owen. R. 1848. On the Archetype and Homologies of the Vertebrate Skeleton. Richard and John E. Taylor, London. https://doi.org/10.5962/bhl.title.118611

Smith, G.A. 1988a. Sedimentology of proximal to distal volcaniclastics dispersed across an active foldbelt: Ellensburg Formation (late Miocene), central Washington. Sedimentology, 35:953-977. https://doi.org/10.1111/j.1365-3091.1988.tb01740.x

Smith, G.A. 1988b. Neogene synvolcanic and syntectonic sedimentation in central Washington. Geological Society of America Bulletin, 100:1479-1492. https://doi.org/10.1130/00167606(1988)100\%3C1479:NSASSI\%3E2.3.CO;2

Smith, G.A., Campbell, N.P., Deacon, M.W., and Shafiqullah, M. 1988. Eruptive style and location of volcanic centers in the Miocene Washington Cascade Range: reconstruction from the sedimentary record. Geology, 16:337-340. https://doi.org/10.1130/00917613(1988)016\%3C0337:ESALOV\%3E2.3.CO;2

Voorhies, M.R. and Perkins, M.E. 1998. Odocoileine deer (?Bretzia) from the Santee Ash locality, late Hemphillian, Nebraska: the oldest New World cervid. Journal of Vertebrate Paleontology, 18:84A.

Vislobokova I., Dmitrieva, E., and Kalmykov N. 1995. Artiodactyls from the Late Pliocene of Udunga, Western Trans-Baikal, Russia. Journal of Vertebrate Paleontology, 15:146-159. https://doi.org/10.1080/02724634.1995.10011214

Waitt, R.B., Jr., 1979. Late Cenozoic deposits, landforms, stratigraphy, and tectonism in Kittitas Valley, Washington. U.S. Geological Survey Professional Paper, 1127:1-18. https://doi.org/ 10.3133/pp1127

Webb, S.D. 2000. Evolutionary history of the New World deer, p. 38-64. In Vrba, E.S. and Schaller, G.B. (eds.), Antelopes, Deer, and Relatives: Fossil Record, Behavioral Ecology, Systematics and Conservation. Yale University Press, New Haven. 
Webb, S.D., Hulbert, R.C., Jr., Morgan, G.S., and Evans, H.F. 2008. Terrestrial mammals of the Palmetto Fauna (early Pliocene, latest Hemphillian) from the Central Florida Phosphate District. Natural History Museum of Los Angeles County, Science Series, 41:293-312.

Zar, J.H. 1999. Biostatistical Analysis (4th edition). Pearson Education India, New Jersey. 


\section{APPENDIX 1}

Measurements and coded characters of Odocoileus hemionus from the Oregon Museum of Natural and Cultural History. For ectostylid, cingulids, and distinct paraconid, 0 indicates complete absence of character, 0.5 indicates ectostylid or paraconid were present, but small, and 1 indicates ectostylid or paraconid were present and prominent. All other values are measurements in millimeters. Abbreviations: AP, anteroposterior measurement; LL, labiolingual.

\begin{tabular}{|c|c|c|c|c|c|c|c|}
\hline Specimen & Tooth & Measurement & Value & Specimen & Tooth & Measurement & Value \\
\hline \multirow{12}{*}{$\begin{array}{l}\text { UOMNCH B- } \\
21654\end{array}$} & \multirow[t]{4}{*}{ m3 } & AP & 21.2 & \multirow{12}{*}{$\begin{array}{l}\text { UOMNCH B- } \\
21672\end{array}$} & \multirow[t]{4}{*}{ m3 } & AP & 18.76 \\
\hline & & LL & 10.32 & & & LL & 8.45 \\
\hline & & Ectostylid & 0.5 & & & Ectostylid & 0 \\
\hline & & Cingulids & 0 & & & Cingulids & 0 \\
\hline & \multirow[t]{4}{*}{$\mathrm{m} 2$} & AP & 18.08 & & \multirow[t]{4}{*}{$\mathrm{m} 2$} & AP & 13.56 \\
\hline & & LL & 10.41 & & & LL & 8.72 \\
\hline & & Ectostylid & 0.5 & & & Ectostylid & 0.5 \\
\hline & & Cingulids & 0 & & & Cingulids & 0 \\
\hline & \multirow[t]{4}{*}{ p2 } & AP & 8.57 & & \multirow[t]{4}{*}{$\mathrm{p} 2$} & AP & 7.9 \\
\hline & & LL & 4.92 & & & LL & 4.93 \\
\hline & & Cingulids & 0 & & & Cingulids & 0 \\
\hline & & Distinct Paraconid & 0.5 & & & Distinct Paraconid & 0 \\
\hline \multirow{12}{*}{$\begin{array}{l}\text { UOMNCH B- } \\
21655\end{array}$} & \multirow[t]{4}{*}{$\mathrm{m} 3$} & AP & 21.5 & \multirow{12}{*}{$\begin{array}{l}\text { UOMNCH B- } \\
21677\end{array}$} & \multirow[t]{4}{*}{$\mathrm{m} 3$} & $\mathrm{AP}$ & 20.46 \\
\hline & & LL & 9.71 & & & LL & 9.86 \\
\hline & & Ectostylid & 0 & & & Ectostylid & 0.5 \\
\hline & & Cingulids & 0 & & & Cingulids & 0 \\
\hline & \multirow[t]{4}{*}{$\mathrm{m} 2$} & AP & 14.87 & & \multirow[t]{4}{*}{$\mathrm{m} 2$} & AP & 16.07 \\
\hline & & LL & 9.42 & & & LL & 9.74 \\
\hline & & Ectostylid & 0 & & & Ectostylid & 0 \\
\hline & & Cingulids & 0 & & & Cingulids & 0 \\
\hline & \multirow[t]{4}{*}{$\mathrm{p} 2$} & AP & 8.56 & & \multirow[t]{4}{*}{$\mathrm{p} 2$} & AP & 9.15 \\
\hline & & LL & 5.1 & & & LL & 5.16 \\
\hline & & Cingulids & 0 & & & Cingulids & 0 \\
\hline & & Distinct Paraconid & 0 & & & Distinct Paraconid & 0.5 \\
\hline \multirow{12}{*}{$\begin{array}{l}\text { UOMNCH B- } \\
21660\end{array}$} & \multirow[t]{4}{*}{$\mathrm{m} 3$} & $\mathrm{AP}$ & 21.46 & \multirow{12}{*}{$\begin{array}{l}\text { UOMNCH B- } \\
21681\end{array}$} & \multirow[t]{4}{*}{ m3 } & $\mathrm{AP}$ & 22.94 \\
\hline & & LL & 9.77 & & & LL & 10.15 \\
\hline & & Ectostylid & 0 & & & Ectostylid & 0.5 \\
\hline & & Cingulids & 0 & & & Cingulids & 0 \\
\hline & \multirow[t]{4}{*}{$\mathrm{m} 2$} & AP & 16.09 & & \multirow[t]{4}{*}{$\mathrm{m} 2$} & AP & 16.88 \\
\hline & & LL & 10.96 & & & LL & 11.12 \\
\hline & & Ectostylid & 0 & & & Ectostylid & 0 \\
\hline & & Cingulids & 0 & & & Cingulids & 0 \\
\hline & \multirow[t]{4}{*}{$\mathrm{p} 2$} & AP & 9.41 & & \multirow[t]{4}{*}{ p2 } & AP & 10.01 \\
\hline & & LL & 6.55 & & & $\mathrm{LL}$ & 6.14 \\
\hline & & Cingulids & 0 & & & Cingulids & 0 \\
\hline & & Distinct Paraconid & 1 & & & Distinct Paraconid & 0 \\
\hline
\end{tabular}


PALAEO-ELECTRONICA.ORG

\begin{tabular}{|c|c|c|c|c|c|c|c|}
\hline Specimen & Tooth & Measurement & Value & Specimen & Tooth & Measurement & Value \\
\hline \multirow{12}{*}{$\begin{array}{l}\text { UOMNCH B- } \\
21687\end{array}$} & \multirow[t]{4}{*}{ m3 } & AP & 21.35 & \multirow{12}{*}{$\begin{array}{l}\text { UOMNCH B- } \\
21690\end{array}$} & \multirow[t]{4}{*}{ m3 } & AP & 10.07 \\
\hline & & $\mathrm{LL}$ & 9.07 & & & LL & 9.74 \\
\hline & & Ectostylid & 0 & & & Ectostylid & 1 \\
\hline & & Cingulids & 0 & & & Cingulids & 0 \\
\hline & \multirow[t]{4}{*}{$\mathrm{m} 2$} & AP & 15.8 & & \multirow[t]{4}{*}{$\mathrm{m} 2$} & AP & 15.39 \\
\hline & & LL & 9.84 & & & LL & 9.37 \\
\hline & & Ectostylid & 0 & & & Ectostylid & 1 \\
\hline & & Cingulids & 0 & & & Cingulids & 0 \\
\hline & \multirow[t]{4}{*}{$\mathrm{p} 2$} & $\mathrm{AP}$ & 9.07 & & \multirow[t]{4}{*}{$\mathrm{p} 2$} & $\mathrm{AP}$ & 8.02 \\
\hline & & LL & 4.73 & & & LL & 5.18 \\
\hline & & Cingulids & 0 & & & Cingulids & 0 \\
\hline & & Distinct Paraconid & 0 & & & Distinct Paraconid & 0 \\
\hline \multirow{12}{*}{$\begin{array}{l}\text { UOMNCH B- } \\
21688\end{array}$} & \multirow[t]{4}{*}{ m3 } & AP & 21.54 & \multirow{12}{*}{$\begin{array}{l}\text { UOMNCH B- } \\
21693\end{array}$} & \multirow[t]{4}{*}{$\mathrm{m} 3$} & $\mathrm{AP}$ & 19.7 \\
\hline & & $\mathrm{LL}$ & 10.18 & & & LL & 10.21 \\
\hline & & Ectostylid & 0 & & & Ectostylid & 0.5 \\
\hline & & Cingulids & 0 & & & Cingulids & 0 \\
\hline & \multirow[t]{4}{*}{$\mathrm{m} 2$} & AP & 17.13 & & \multirow[t]{4}{*}{$\mathrm{m} 2$} & AP & 16.23 \\
\hline & & $\mathrm{LL}$ & 10.82 & & & LL & 10.58 \\
\hline & & Ectostylid & 0 & & & Ectostylid & 0.5 \\
\hline & & Cingulids & 0 & & & Cingulids & 0 \\
\hline & \multirow[t]{4}{*}{ p2 } & AP & 10.01 & & \multirow[t]{4}{*}{ p2 } & AP & na \\
\hline & & LL & 6.19 & & & LL & na \\
\hline & & Cingulids & 0 & & & Cingulids & na \\
\hline & & Distinct Paraconid & 1 & & & Distinct Paraconid & na \\
\hline
\end{tabular}

